\title{
A DEMOCRACIA REPRESENTATIVA NO BRASIL
}

THE REPRESENTATIVE DEMOCRACY IN BRAZIL

Fabiano Yuji Takayanagi ${ }^{1}$

\begin{abstract}
Resumo:
Trata-se de um estudo baseado na História do Brasil para uma análise da evolução da democracia representativa no País tupiniquim, bem como um exame crítico sobre a crise dos partidos políticos que, hoje, em pleno século XXI, não passam de meras siglas como foi comprovado nas eleições de 2006. Percebe-se, assim, que não defendem uma ideologia, apenas interesses de uma minoria, se não próprios, em detrimento de uma coletividade.

Por derradeiro, inclui-se nessa pesquisa a demonstração do povo em sua discórdia quanto ao colapso da democracia representativa, quando vivenciamos a manifestação pelo voto nulo contradizendo claramente o princípio almejado ferozmente no marcante movimento "Diretas-Já", o voto popular.
\end{abstract}

Palavras-chave: Democracia representativa. Crise dos partidos políticos. Voto nulo.

\begin{abstract}
:
The paper is a study based in the History of Brazil, and intends to investigate the evolution of the representative democracy in our country, as well as analyses the crisis of the political parties that, today, in the very Century XXI, do not go beyond mere acronyms, what was proved in the last elections of 2006. It is clear, then, that they do not support an ideology, but just interests of a minority, if not their own, in spite of the will of the coletivity.

Concluding, it was included in this research the demonstration of a people in their contention about the collapse of the representative democracy, when we see now the society willing the nule vote, clearly contradicting the fiercely aimed popular vote, in the move called "Diretas-Já" [Directs Now].
\end{abstract}

Keywords: Representative democracy. Crisis of the political parties. Nule vote.

\section{Introdução}

O objetivo deste trabalho é tentar explicar a situação da atual democracia representativa brasileira em que se percebe existir um lapso para uma coesão de todo o País.

A democracia, segundo a Enciclopédia Larousse Cultural, ${ }^{2}$ vem do grego demokrateia, governo do povo e é um regime político que se funda na soberania popular, na liberdade eleitoral, na divisão de poderes e no controle da autoridade. Portanto, é um

\footnotetext{
1 Aluno do Curso de Graduação da Faculdade de Direito da Universidade de São Paulo.

2 GRANDE Enciclopédia Larousse Cultural, Ed. Nova Cultural
} 
sistema de relações estabelecidas no interior de uma instituição, de um grupo, que leva em consideração, em seus diversos níveis hierárquicos, as opiniões de todos os responsáveis pelas tarefas a serem cumpridas.

A Enciclopédia ${ }^{3}$ classifica a democracia em níveis: a democracia cristã que é uma doutrina política, econômica e social que tende a conciliar os imperativos da fé e da moral cristã e os princípios democráticos; a democracia direta em que o povo, nesse sistema político, exerce sua soberania sem um intermédio de um órgão representativo; a democracia popular que são os regimes de países socialistas; democracia representativa, isto é, um sistema político no qual o povo exerce sua soberania por intermédio de órgãos representativos; e a democracia social que é um sistema político no qual o povo exerce sua soberania tanto no domínio econômico social como no político.

Esta pesquisa, por conseguinte, estará voltada para um sistema político no qual o povo exerce sua soberania por intermédio de órgãos representativos, conforme a ideologia de Rousseau", cuja sua obra o Contrato Social prega que "Cada um de nós põe em comum sua pessoa e todo o seu poder sob a suprema direção da vontade geral, e recebemos, enquanto corpo, cada membro como parte divisível do todo." Esse ato de associação em detrimento da vontade particular faz com que ela passe a ser coletiva. A pessoa pública representaria um todo, o bem de um todo, logo a frase "Todo poder emana do povo", do pensador francês, representaria o ideal democrático.

Sendo assim, utilizaremos a História, a fim de acompanhar a evolução dessa engrenagem política que parece, atualmente, estar em degenerescência, e talvez possamos achar respostas, por exemplo, para a discordância entre a luta pelo voto direto em fins de Ditadura Militar e sua anulação nas últimas eleições de 2006, ou então para a aliança entre partidos políticos antagônicos de ideologias divergentes.

\footnotetext{
3 Id. Ibid.

4 WEFFORT, Francisco C. Os clássicos da politica. 13. ed. São Paulo: Ed. Ática, 2005. v. 01
} 
Capítulo $I^{5 / 6 / 7 / 8 / 9}$

1. A História de uma futura nação

1.1. Brasil, um território "descoberto"

O Brasil foi uma conseqüência de um processo de expansão marítima européia. Os países ibéricos, com o Capitalismo Mercantil, foram os pioneiros a se aventurarem pelos oceanos graças a seus investimentos estatais resultantes do Estado Moderno centralizado e às aparelhagens tecnológicas para a navegação nos mares. Tudo isso proporcionou aos portugueses e espanhóis a busca de novos continentes com o intuito de enriquecimento e aumento do poder das coroas absolutistas. Assim, o País tupiniquim fora "descoberto" em época da Idade Moderna, no século XVI.

Cabe ressaltar que essa "descoberta” é questionável, pois sabe-se que, antes da chegada dos portugueses ao continente sul-americano, aqui já habitavam os índios. Desse modo, seria correto afirmar que a História contada pelos europeus demonstra um ponto de vista puramente eurocêntrico.

O Mercantilismo foi a causa inicial do empreendimento lusitano no Brasil e uma espécie de política econômica adotada pelos Estados Reais Absolutistas durante a Idade Moderna (século XV a XVIII). Tinha como objetivo o desenvolvimento do comércio nacional europeu com a finalidade de se obter a hegemonia européia e fortalecer o poder político do Estado Real através de uma receita tributária maior, ou seja, quanto maior fosse o comércio nacional, maior a receita tributária, em conseqüência, maior seria o poder político do Estado na Europa.

\subsection{Brasil-Colônia}

Não houve um interesse tão grande de Portugal pelo País recém descoberto. Isso porque, diferente da Espanha, que dominara regiões como a atual América Central e parte da costa oeste da América do Sul, encontrando os cobiçados metais preciosos como

\footnotetext{
5 NADAI, Elza; NEVES, Joana. História do Brasil. 20. ed. São Paulo: Ed. Saraiva, 1997.

6 VICENTINO, Claudio; DORIGO, Gianpaolo. História do Brasil. 1. ed. São Paulo: Ed. Scipione, 1999.

7 FERREIRA, Olavo Leonel. História do Brasil. 8. ed. São Paulo: Ed. Ática, 2005.

8 COSTA, Luis Cesar Amad; MELlo, Leonel Itaussu. A história do Brasil. 11. ed. São Paulo: Ed. Scipione, 2002.

9 HOLANDA, Sérgio Buarque de. Raizes do Brasil. 26. ed. São Paulo: Cia das Letras, 1995.
} 
ouro e prata, o Brasil não parecia possuir tais fortunas, somente produtos naturais como o pau-brasil, com o qual se extraía o corante de cor vermelha que tinha valor comercial inferior aos preciosos metais do vizinho ibérico.

Posteriormente, a necessidade de colonização tornou-se uma obrigação, pois Portugal tinha que garantir a posse da terra, a fim de explorá-la por causa da decadência do comércio asiático português.

O investimento inicial no Brasil foi a grande empresa açucareira, já testado em outras colônias como Ilhas da Madeira e Açores. O açúcar, na época, era um produto raro, uma especiaria de valor elevado no mercado. O clima e o solo brasileiros eram favoráveis e o produto era de fácil transporte por não ser perecível.

Os primeiros colonizadores eram portugueses da pequena nobreza, desterrados e de poucos recursos financeiros. O objetivo era único: tentar enriquecer.

A montagem da empresa açucareira exigia elevados capitais iniciais, pelo fato de necessitar de equipamentos do engenho e mão-de-obra caríssima, os escravos negros. A saída foi uma parceria com os flamengos que financiaram a produção; transportaram o produto; tiveram o monopólio da refinação e distribuíram o produto no mercado europeu, agregando ao açúcar um alto valor.

O sistema adotado foi o monocultor-latifundiário, porque produção em grandes propriedades rurais era rentável e lucrativa para cobrir os altos custos de investimentos. Foi ainda escravista, pois a produção voltada apenas ao mercado externo, exigia baixo custo.

As conseqüências do sistema escravista adotado foram: a desvalorização do trabalho manual; a naturalidade com que os senhores-de-engenho consideravam o escravo negro como coisa; a baixa produtividade, pois os escravos não tinham estímulos, somente castigos, fome, desnutrição e longas jornadas de trabalho; e a concentração da renda nas mãos do grupo senhorial.

Sendo assim, define-se essa sociedade colonial como rural (em que as cidades eram poucas e muito pequenas), escravista, patriarcal, aristocrática e estratificada.

$\mathrm{O}$ auge da economia açucareira teve seu declínio após a afrouxamento da aliança entre Portugal e os holandeses devido à União Ibérica (1580/1640). A Holanda dominou o Nordeste do Brasil, especificamente Pernambuco, e lá se estabeleceu de 1630 até 1654, quando os flamengos foram expulsos do País. Isso trouxe como conseqüência para Portugal a perda de capitais e do mercado europeu na distribuição do açúcar. 


\subsubsection{A estrutura político-administrativa}

A estrutura criada para administrar a colônia foi a das Capitanias Hereditárias (1534 a 1549) em que os donatários eram os administradores políticos, tinham direitos como doar sesmarias, isto é, os latifúndios aos colonos, cobrar impostos dos colonos que habitassem suas capitanias, praticar a justiça, fundar vilas e escravizar índios hostis. Tinham também deveres como atrair colonos, estimular a produção econômica e defender militarmente a sua Capitania.

Essa primeira experiência, com exceção da Capitania de Pernambuco, fracassou, pois a Coroa, querendo acelerar a colonização, transferiu as elevadas despesas à iniciativa privada.

O Sistema de Governo Geral foi implantado por volta de 1549 como tentativa de superar o fracasso das capitanias. Tinha o objetivo de centralizar o poder político para melhor controlar e fiscalizar os donatários, assim como coordenar a defesa militar da Colônia contra invasões estrangeiras.

Um fato importante na época colonial foi a instauração das Câmaras Municipais. Elas somente existiam nas vilas e funcionavam como as "prefeituras" atuais. A lei determinava que apenas os "Homens Bons" poderiam votar e ser eleitos. A definição de "Homem Bom" era aquele que fosse branco, católico e tivesse cabedal, isto é, possuísse riquezas, patrimônios. A maioria deles era aristocratas rurais, senhores-de-engenho, fazendeiros, comerciantes e altos funcionários.

Essas Câmaras eram um instrumento de poder político da camada dominante local. E analisando toda a organização política desse período, percebemos um caráter elitista, cujo objetivo era a defesa de interesses particulares e não-coletivos, afastando qualquer iniciativa de democracia em uma sociedade mergulhada nos princípios do patriarcalismo.

\subsection{A expansão territorial}

A expansão territorial foi conseqüência de atividades secundárias à monocultura como a pecuária que fixou homens nos atuais Estados do Rio Grande do Sul, Goiás, Mato Grosso, Minas Gerias e regiões do sertão do Nordeste. Também nas atividades militares na fundação de fortes, de exploração econômica como se deu na busca das "drogas-do-sertão" no vale amazônico e o empreendimento na plantação de algodão, na região do Maranhão, em época de Revolução Industrial Inglesa e Guerra de 
Independência dos Estados Unidos da América, foram responsáveis pelo alargamento das fronteiras do Brasil.

A mineração igualmente merece destaque nessa época de expansão e declínio da Colônia, pois foi responsável pela interiorização e povoamento de grande contingente em regiões desconhecidas e também foi um elo para a criação e o desenvolvimento de uma classe média, que posteriormente fez rebeliões em busca de mudanças político-sociais.

A atividade extrativa de minerais deu-se em locais como os atuais Estados de Minas Gerias, Goiás, Mato Grosso e o Sul da Bahia. Iniciou-se o desenvolvimento do trabalho livre, pois muitos senhores-de-escravos davam-lhes a alforria, em troca de uma grande quantidade de ouro. Assim, esses escravos libertos, mulatos e outros passaram a compor a camada média da população, até então inexistente.

\subsection{O declínio do Brasil-Colônia e a sua Independência}

Diversos fatores como a independência das colônias na Revolução de Escravos do Haiti que o separou da França e a Independência das 13 colônias, libertandose da Inglaterra, comprovam a possibilidade de revolução contra as respectivas metrópoles em busca de autonomia. O colapso do antigo sistema político absolutista dando lugar ao novo sistema Liberal e o crescimento de uma burguesia industrial modificaram antigos pensamentos político-econômicos para uma inovação estrutural e um mundo capitalista em que o Liberalismo econômico, de Adam Smith, passou a vigorar.

Os reflexos para o Brasil vieram diferentemente da maioria das revoluções separatistas e a Independência do País ocorreu pela introdução de um regime aristocrático, cujo líder era um Rei iniciando o Primeiro Império brasileiro que manteve o binômio latifúndio-escravidão .

O monarca D. Pedro I formou uma Assembléia, a fim de elaborar a primeira Constituição brasileira e estabelecer as diretrizes do Brasil-independente. Foi nesse período que os primeiros partidos políticos surgiram com objetivo de defender seus interesses. Eram dois os partidos: o Partido Brasileiro, composto pela aristocracia rural, tinha como interesse consolidar a Independência, limitar o poder real, impor o sufrágio censitário e instituir o Liberalismo político; e o Partido Português, formado por comerciantes lusos e pela alta burguesia estatal cujo interesse era manter o Absolutismo.

Podemos inferir, por meio desse bipartidarismo, que os primeiros partidos políticos não defendiam ideais de uma coletividade e, sim, interesses privados de uma 
minoria da camada privilegiada em detrimento da parcela excluída e pobre da sociedade imperial.

A marca desse período foi a Constituição, outorgada de 1824, que estabelecia um regime monárquico, constitucional e representativo (eleições legislativas). O Brasil era um Estado Unitário. O sufrágio era permitido aos homens maiores de 25 anos e o voto censitário e aberto, estimulando as fraudes eleitorais. D. Pedro I criou quatro poderes de Estado: Legislativo, exercido pela Assembléia Geral bicameral; Executivo, em que o imperador era o governante auxiliado pelos ministros; Judiciário, chefiado pelos juízes em tribunais; e o Moderador que era uma espécie de poder preventivo de uso exclusivo do Imperador, a fim de estabelecer a ordem nos demais Poderes.

O moderno conceito de democracia fica prejudicado nesse modelo, pois a exclusão, por exemplo, na defesa do sufrágio censitário pelo Partido Brasileiro e posteriormente estabelecido na Constituição, de 1824, justifica o pensamento elitista predominante na época. Além disso, a idéia de representatividade estaria longe de se concretizar, pois os deputados e senadores seriam eleitos por uma minoria, a aristocracia rural, o que não traria benefícios às demais camadas da sociedade como é ideal em uma real democracia representativa.

\subsection{O Período Regencial}

A impopularidade de D. Pedro I crescia e os fatos como o aumento da pobreza, crise na economia, manutenção do latifúndio e a escravidão, voto censitário e problemas com revoltas internas e guerras externas culminaram com sua abdicação e retorno a Portugal.

No entanto, o Brasil não ficou sem governante, pois o imperador deixou seu filho, ainda menor de idade, como sucessor do trono brasileiro. Durante a minoridade, o País teve regentes como governantes provisórios do Poder Executivo, que eram representantes das elites aristocráticas brasileiras.

Essa foi uma fase de descentralização política e algumas medidas federalistas foram tomadas. A Regência Trina vigente foi substituída pela Regência Una que passou a ser eletiva por meio de voto censitário e temporária com um mandato de quatro anos. Percebemos uma espécie de experiência republicana de governo apesar de ainda elitista. Houve também a criação de Assembléias Legislativas Provinciais que eram compostas por deputados eleitos que criavam leis provinciais com forte poder. 
1.6. O Golpe da Maioridade e o II Império

O Golpe da Maioridade consistiu em um plano organizado pelo Partido Liberal juntamente com setores do Partido Conservador pela antecipação da entrega do trono brasileiro ao príncipe D. Pedro II, iniciando o Segundo Império brasileiro.

O período foi marcado principalmente por mudanças sócio-econômicas provocadas pelo fim do tráfico negreiro e a expansão da cafeicultura no oeste paulista. Iniciou-se o crescimento urbano e a diversificação da estrutura social com o aumento do trabalho livre e assalariado bem como a expansão das camadas médias urbanas e o surgimento de uma nova elite: a burguesia cafeeira do Oeste paulista. Desse modo, surgiu uma oposição de interesses entre a aristocracia escravocrata, a burguesia cafeeira do Oeste paulista e as camadas médias urbanas.

Aos poucos, D. Pedro II passou a se isolar no poder. O conflito com o Exército que não recebera o reconhecimento esperado por seu desempenho na Guerra Cisplatina culminou na sua perda de poder militar. O imperador também ficou sem o apoio da Igreja devido à recusa ao pedido do clero que exigia autonomia em relação ao Estado, e a camada aristocrática, por sua vez, não o defendia porque ficara privada dos privilégios da escravidão.

O resultado desse isolamento foi a fuga do imperador para Portugal e a Proclamação da República, em 15 de novembro de 1889.

\subsection{Sobre os Partidos Políticos}

O Partido Português, que deu origem ao Partido Restaurador ou Caramuru, tinha como objetivo a volta de D. Pedro I ao trono. Existiu de 1831 a 1834.

O Partido Brasileiro segmentou-se em dois: o Partido Liberal Moderado ou Chimango, formado pela aristocracia rural que defendia a manutenção da ordem, monopolizou o poder, em 1831, e o Partido Liberal Exaltado ou Farroupilha, formado pelas camadas médias urbanas que defendiam revoltas para criar o voto universal e o Federalismo. Existiu entre 1831 a 1835.

O Partido Liberal Moderado deu origem, em 1835, a dois novos partidos políticos: o Partido Regressista, que buscava o centralismo político e que posteriormente se transformou no Partido Conservador, e o Partido Progressista que buscava a descentralização política, o Federalismo, posteriormente transformando-se no Partido Liberal. 
Os Partidos Liberal e Conservador tinham poucas diferenças. Ambos representavam a aristocracia rural e tinham ideologias muito parecidas. Sendo assim, a antagonismo era quase nulo na teoria, pois, na prática, havia uma disputa violenta pelo poder. Isso somente teve fim por meio de um acordo entre partidos, a chamada Política da Conciliação, demonstrando a diferença mínima nas ideologias.

Capítulo II $10 / 11 / 12 / 13 / 14 /$

\subsection{Uma Nação republicana}

\subsubsection{O Continuísmo na República}

\section{Conforme salienta Francisco Weffort: ${ }^{15}$}
(...) assim como na passagem da colônia para o Primeiro Reinado, também na passagem do Império para a República alguns cronistas sentiram-se tentados a reafirmar a continuidade de uma história que mantém fortes vínculos com o passado. Falou-se muito em "República dos Conselheiros", em alusão à permanência dos grandes nomes do Império nos primeiros governos republicanos.

Sendo assim, é de se esperar uma República excludente e elitista. Analisaremos, pois, essa situação até chegarmos à implantação da democracia efetiva e suas oscilações causadas por governos autoritários.

\subsubsection{A República da Espada}

A República foi proclamada por militares e com a ausência do povo.

O primeiro presidente do Brasil foi o militar Marechal Deodoro da Fonseca eleito pelo Congresso Nacional, via eleição indireta. Uma das medidas de grande relevância foi a separação do Estado da Igreja, ou seja, a laicização do Estado. Outro importante fato foi a promulgação da Constituição, de 1891, cujo regime era republicano, presidencialista

\footnotetext{
10 NADAI, Elza; NEVES, Joana. História do Brasil. 20. ed. São Paulo: Ed. Saraiva, 1997.

11 VICENTINO, Claudio; DORIGO, Gianpaolo. História do Brasil. 1.ed. São Paulo: Ed. Scipione.

12 FERREIRA, Olavo Leonel. História do Brasil. 8.ed. São Paulo: Ed. Ática, 2005.

${ }^{13}$ COSTA, Luis Cesar Amad; MELLO, Leonel Itaussu A. op. cit.

14 HOLANDA, Sérgio Buarque de. op. cit.

15 WEFFORT, Francisco C. op. cit..
} 
e federalista. O sufrágio, ainda excludente, ficava restrito aos homens alfabetizados. O voto seria aberto permitindo o "voto de cabresto" e a formação de "currais eleitorais".

Pelo fato de tentar continuar no governo por meio de um golpe de estado, foi expulso por uma resistência dos militares contra o Marechal.

O segundo presidente, Marechal Floriano Peixoto, também era um militar. Ele derrubou os governadores de Estados, nomeando interventores militares em seus lugares, impôs um centralismo político desobedecendo ao Federalismo e, para conquistar o apoio das massas, tabelou preços e aumentou o salário dos funcionários públicos.

No entanto, as oligarquias, temendo Floriano Peixoto, unem-se para que no fim de seu mandato não se reelegesse.

\subsubsection{A República Oligárquica}

As oligarquias cafeeiras assumiram o controle do Governo federal. Excluíram as políticas adotadas pelo antigo presidente e passaram a estabelecer um sistema político de alternância de poder, isto é, as oligarquias mais proeminentes do Brasil, a de São Paulo e a de Minas Gerais, uniriam-se e alternaram seus respectivos representantes nos cargos à Presidência. Por isso, muitos historiadores chamavam esse período de a "A República Café-com-Leite".

O primeiro presidente civil, Prudente de Moraes, teve como maior desafio vencer a Guerra de Canudos, muito bem descrita por Euclides da Cunha no livro "Os Sertões". Essa obra serviu como instrumento de divulgação da realidade do interior do Brasil e das mazelas de uma sociedade desigual.

O presidente seguinte foi Campos Salles e seu artífice mais evidente foi a criação da "Política dos Governadores" que consistia em uma troca de favores, na qual os governadores de Estado apoiavam o presidente em qualquer decisão e este lhes daria privilégios. Campos Salles criou um pacto oligárquico em que, na esfera federal, teria o apoio das oligarquias cafeeiras, na esfera estadual, contaria com os privilégios concedidos a essas oligarquias e, para garantir o poder das elites, criou-se o poder municipal baseado na mesma troca de favores em que os representantes dessa esfera eram coronéis que administravam a política do coronelismo.

Rodrigues Alves é o terceiro presidente. Foi no seu governo que houve a criação do "Convênio de Taubaté", uma política de valorização do café, no qual o País comprava café excedente tirando-o do mercado para valorizar seu preço mundial. Assim, 
o Governo usava o dinheiro público para a compra e a estocagem com a finalidade de garantir o lucro dos empresários do café.

Depois de problemas sucessórios e a primeira cisão da "Política Café-comLeite", um novo militar volta à Presidência, o Marechal Hermes da Fonseca. Seu desafio foi enfrentar uma revolta de marinheiros insatisfeitos com suas péssimas condições de vida, era a Revolta da Chibata.

No entanto, a marca de seu governo fora a criação da "Política das Salvações"; era uma política determinada por Hermes baseada na substituição dos oligarcas dominantes por outros de sua confiança, inclusive parentes. Sua justificativa para tal ato era a necessidade de salvar a pureza dos ideais republicanos, combater as fraudes e a corrupção.

Vendo essa drástica e forçada mudança, as oligarquias de SP e MG se unem e conseguem eleger Wenceslau Brás, em 1914, para presidente. Nesse período houve um surto industrial devido a eclosão da Primeira Guerra Mundial que desarticulara o comércio internacional e o Brasil investira nas indústrias de substituição de importação. Além disso, Brás teve que conter uma violenta revolta que, mais uma vez, demonstrou as mazelas do interior do País, a Revolta do Contestado na fronteira de PR e SC.

Depois de Wenceslau Brás, o País passa por uma nova crise da República Oligárquica devido à mudanças sócio-econômicas. A expansão da indústria causou uma explosão demográfica e acelerada urbanização. Houve o fortalecimento da burguesia industrial e o crescimento da classe média urbana, esta última estava irritada pelas fraudes eleitorais e a corrupção e exigia a "purificação do Estado" (a ética na política). Seu auge foi a criação do Partido Democrático, em 1926, que estaria em oposição ao Partido Republicano Paulista.

Foi nessa época que nasceu a classe operária que passou a protestar em busca de reivindicações e a fazer greves. E, em 1917, foi a Primeira Greve Geral reivindicando maiores salários, jornada de trabalho de 8 horas e a proibição de trabalhos infantis e de trabalho feminino no período noturno. Em 1922, funda-se o Partido Comunista Brasileiro de caráter marxista-revolucionário.

Artur Bernardes ocupou o cargo da Presidência, em 1922, depois de vencer a oposição criada pela união de oligarquias dissidentes do RS, RJ, BA e PE, a chamada "Reação Republicana". E foi nesse ano que eclodiu a Primeira Revolta Tenentista, que tinha o objetivo de derrubar o Governo oligárquico e implantar reformas como o voto secreto, programas de alfabetização, leis trabalhistas e o apoio à indústria nacional. Muitos 
historiadores afirmam que a dura repressão aos tenentistas foi o início da Revolução de 1930.

Bernardes governou o quadriênio em estado de sítio, prendeu milhares de pessoas e censurou severamente a Imprensa. Ele reprimiu outras revoltas tenentistas como a Revolução Paulista, em 1924, e a Revolta Gaúcha, mas frustrou-se pela incapacidade de aniquilar com a Coluna Prestes que permaneceu impune e se dispersou, deixando um ar de esperança aos brasileiros.

\subsection{A Revolução de 1930}

A hegemonia da "Política Café-com-Leite" começou a ruir. Os anos de dominação do poder causaram indignação às demais oligarquias que passaram a se unir e transformaram-se em uma frente de oposição. A classe média e operária se encontravam ainda excluídas, mas os meios de se expressarem tornaram-se plausíveis e palpáveis, pois contavam com a Imprensa e um contingente populacional significativo, conseqüência da urbanização.

A última cisão das oligarquias de SP e MG culminou no seu fim, pois a "Aliança Liberal", formada em 1929, por Oligarquias dissidentes e insatisfeitas não permitiu a vitória fraudulenta do representante de SP. Assim, juntamente com os tenentistas, a "Aliança Liberal” toma o poder estabelecendo o "Governo Provisório" com o líder Getúlio Vargas.

\subsection{O Governo Provisório}

O Governo Provisório perdurou de 1930 a 1934. Foi uma ditadura política em que houve a revogação da Constituição, de 1891, o Poder Legislativo foi fechado e nomearam-se interventores militares, os tenentistas, para ocupar os cargos dos antigos governadores e prefeitos.

A reação mais violenta frente à nova situação do Brasil fora a Revolução Constitucionalista, de 1932. Era planejada pela Frente Única Paulista (FUP) e liderada pela Oligarquia Cafeeira (Partido Republicano Paulista) e apoiada pela burguesia industrial e setores da classe média (Partido Democrático). O seu maior objetivo era derrubar o Governo Provisório e instituir uma Constituição. Resultou no total isolamento paulista e dura repressão por parte do Governo.

Em 1934, promulga-se a terceira Constituição do Brasil. Ela propunha, além da República presidencialista, federalista e liberal, leis trabalhistas, portanto, a 
incorporação das massas urbanas à vida urbana; o sufrágio feminino com voto secreto e restrito somente a alfabetizados; criou-se a Justiça Eleitoral e a Justiça Trabalhista.

Com a nova Constituição, há o inicio do Governo Constitucional de Vargas.

\subsection{O Governo Constitucional}

Getúlio Vargas foi eleito presidente via eleição indireta organizada e votada pelo Congresso Nacional.

Nesse período, persistiu uma radicalização ideológica em que surgiram diversos partido políticos. Um deles era a Ação Integralista Brasileira - AIB (ou Fascismo Caboclo) com o líder Plínio Salgado e visava o totalitarismo, o Estado sem oposição; um anticomunismo radical; um ultranacionalismo; e o corporativismo em que o Estado controlaria as corporações profissionais. Em oposição à AIB havia a Aliança Nacional Libertadora - ANL, era uma frente política de esquerda, muito heterogênea, liderada por comunistas e visava a reforma agrária; o não-pagamento da dívida externa, a nacionalização de empresas estrangeiras; e um governo popular e democrático. Embora os dois partidos tivessem siglas diferentes, ambos eram nacionalistas; antiliberais; anti-individualismo, não se respeitava o direito de uma minoria; e autoritários.

O Governo Constitucional teve seu fim por um golpe de estado, organizado pelo presidente, em que se afirmava o estado de perigo vivido pelo Brasil frente a uma ameaça comunista. Era o "Plano Cohen".

\subsection{O Estado Novo}

Foi uma ditadura política de traços fascistas. Vargas, no poder, fechou o Poder Legislativo e proibiu os partidos políticos. Ele derrubou todos os governadores e prefeitos, eleitos em 1934, e nomeou interventores federais favoráveis à ditadura. Foi a imposição de um regime unitarista.

A recém-Constituição de 1934 fora anulada em lugar da imposição da Constituição outorgada de 1937, “a Polaca”, baseada no programa do partido nazista da Polônia. Transformou o Governo em um presidencialismo autocrático; assim, Vargas tinha o Poder Executivo, Legislativo e controlava o Judiciário. Tinha a força da Polícia Especial e criou o Departamento de Imprensa de Propaganda - DIP que servia como controle da Imprensa para inserir propagandas nacionalistas e excluir a Imprensa política e artística. 


\subsubsection{Getúlio Vargas}

A Era Vargas se iniciou após a vitória das oligarquias dissidentes. O Brasil se encontrava em um colapso da economia agroexportadora devido à crise de 1929 e a baixa do preço do café. Getúlio Vargas praticava a política de comprar e destruir a safra excedente de café e ao mesmo tempo exigia a redução da produção e estimulava a policultura. Isso evitou com que os preços mundiais do café caíssem ainda mais.

Essa atitude impediu a falência dos cafeicultores, pois o País dependia da monocultura e, assim, outros setores da economia continuaram funcionando e o desemprego foi relativamente pequeno. Em outra parte da economia havia o incentivo à industrialização, em detrimento da importação, por meio da eliminação da capacidade ociosa das fábricas e havia investimentos em equipamentos mais modernos. Além disso, existia a forte presença do Estado nas políticas econômicas, o protecionismo estatal e a adoção de uma política nacionalista com a criação de indústrias de base nacionais.

Vargas se resumia em um personagem populista em que o Governo era formado pelas oligarquias dissidentes, por setores da burguesia industrial e financeira, e setores da classe média. O objetivo do populismo era controlar as massas populares urbanas por meio de benefícios paternalistas como na publicação, em 1943, da CLT, um Código de Leis Trabalhistas reforçando a imagem de "pai dos pobres". E para evitar desgostos do operariado crescente, o governante controlava os sindicatos pelo sindicalismo pelego, o corporativismo fascista, em que líder sindicalista ao invés de lutar pela causa dos sindicatos, era pró-governo em suas decisões.

Getúlio Vargas criou assim todo um aparato de centralização do poder federal nas mãos de uma única pessoa. Apesar de tornar o Governo autoritário, o presidente recebia o apoio do povo pelo seu carisma e sua fama de paternalista.

Conforme explica Max Weber em "Ensaios de Sociologia"16 o carisma seria a vocação política mais elevada. Os homens não o obedeceriam em virtude da tradição ou da lei, mas porque acreditariam nele. A dedicação de seus discípulos, seus seguidores, seus amigos pessoais do partido seria orientada para a sua pessoa e para suas qualidades. Isso era o que ocorria com os seguidores de Getúlio Vargas, o "Pai dos Pobres".

\footnotetext{
16 WEBER, Max. Ensaio de sociologia. Rio de Janeiro: Zahar Editores, 2000.
} 


\subsection{A volta da República}

O Brasil, ainda com Getúlio Vargas no poder, entra na Segunda Guerra Mundial, apesar de se manter neutro. Foi somente em setembro de 1944 que o País tropical resolve apoiar um lado, os Estados Unidos da América. O objetivo era implantar a democracia nos países rivais.

Aqui percebemos uma grande contradição, pois enquanto o Brasil lutava pela democracia na política externa, na política interna o regime era totalitário, ditatorial. Isso gerou protestos e o resultado foi a redemocratização brasileira. As eleições foram marcadas para dezembro de 1945 e foi concedida a liberdade partidária.

Assim, surgiram muitos partidos políticos como o PTB, composto por líderes sindicalistas pelegos e alguns nacionalistas; o PSD formado por políticos autoritários do Estado Novo, oligarquias latifundiárias e industriais, banqueiros e comerciantes; a UDN, composta por políticos liberais, alta burguesia comercial, fazendeiros de vários estados, banqueiros e industriais cariocas; o PCB, composto por comunistas que defendiam o modelo socialista soviético (stalinismo).

A aliança partidária, PSD e PTB, conseguiu eleger o presidente Dutra. Ele promulgou a Constituição, de 1946 redemocratizando o País. Entretanto no poder ainda existiam grupos autoritários do Estado Novo, mostrando o conservadorismo presente. Foi em seu Governo que houve a proibição do PCB, devido a sua relação amistosa com os EUA.

Na eleição seguinte, 1951, Getúlio Vargas por meio da aliança PSD e PTB consegue voltar ao poder. O presidente continuou com o seu populismo, aumentando o salário mínimo em $100 \%$ e pôs em ação seu "Plano Lafer" em que consistia em uma política econômica de intervencionismo estatal com caráter protecionista e nacionalista. Houve a criação de novas estatais o BNDE(s) e a Petrobras.

A oposição contrariada conspira contra Getúlio na forma de um golpe de estado, porém o plano fora fracassado, pois o "pai dos pobres" se suicidara, em 1954.

Após turbulentas sucessões presidenciais, em 1956, novamente por meio de uma aliança PSD e PTB, Juscelino Kubitschek se elege presidente. Sua política adotada era a desenvolvimentista e seu slogan era "50 anos em 5", para demonstrar as evoluções pretendidas trazer ao Brasil. Juscelino impulsionou a economia brasileira, trazendo inovações como as diversas transnacionais; porém, isso tudo deu o inicio ao capitalismo associado à dependência. A política econômica adotada desnacionalizou a economia, isto 
é, setores inteiros passaram a estar no controle internacional, e acentuou as disparidades regionais.

O próximo presidente, Jânio Quadros, do partido da UDN, era um conservador, autoritário e demagogo. A economia estava num processo de inflação e tinha uma forte oposição por parte das indústrias e dos sindicatos dos operários. A política externa estava baseada no isolamento, o que enfraqueceu o Brasil e tudo isso quase culminou em um golpe de estado com liderança dos militares.

O golpe não ocorreu, pois havia um forte resistência pró-democracia e a eleição para o próximo presidente foi garantida.

João Goulart torna-se o novo presidente, em 1961, antes de uma grande mudança na democracia brasileira. Para reduzir os poderes de Jango, pseudôniomo do presidente, o Parlamentarismo foi adotado, pois alegavam suspeitas de idéias comunistas do presidente. O País viveu essa experiência parlamentarista até 1963, quando o sistema presidencialista volta em vigor.

O presidente João Goulart propusera muitas reformas como a agrária, bancária, tributária e eleitoral que não agradaram as camadas da elite. O clima de golpismo estava já se concretizando. Até que, em 1964, os militares alegando instabilidade da democracia, tomaram o poder federal.

\subsection{A Ditadura Militar}

Foi um período de grande repressão. Durou de 1964 a 1985. A política econômica adotada nessa época foi de achatamento de salários, proibição de greves e repressão de sindicatos; houve estímulos estatais para as grandes empresas nacionais; atração das multinacionais, em 1970 era o "paraíso das multinacionais"; houve também um elevado investimento em infra-estrutura, principalmente em energia, transportes e telecomunicações. O capitalismo associado e dependente ao Exterior foi consolidado e este era baseado em um tripé, isto é, as grandes estatais no topo, e as multinacionais e grandes empresas nacionais privadas se encontravam na base.

As conseqüências foram o crescimento econômico elevado, a grande concentração de renda, pouco investimento nas áreas sociais e uma dívida externa impagável com um exorbitante déficit público e uma superinflação. A economia posteriormente estagnou e culminou em números altos de desemprego.

Os presidentes foram cinco militares: o Marechal Humberto de Alencar Castello Branco (1964 a 1967), o General Artur da Costa e Silva (1967 a 1969), o General 
Emílio Garrastazu Médici (1969 a 1974), o General Ernesto Geisel (1974 a 1979) e o General João Baptista Figueiredo (1979 a 1985). Houve uma montagem de um regime ditatorial com a imposição dos Atos Institucionais, que eram medidas de força, de execução.

Os principais Atos Institucionais foram:AI-1 de abril de 1964 que determinava poderes aos presidentes de cassar mandatos políticos, suspender direitos políticos e decretar estado de sítio sem a autorização do Congresso nacional. Isso enfraqueceu o Poder Legislativo e o Judiciário em contrapartida fortaleceu demasiadamente o Poder Executivo; o AI-2 de outubro de 1965 determinava a extinção de todos os partidos políticos e a criação do bipartidarismo: a Arena, os que apoiavam o regime, e o MDB, a frente política de oposição ideológica. Eram partidos artificiais. O AI-2 também estabelecia eleições indiretas para presidente da República e este seria quem elegeria o Colégio Eleitoral. No AI-3 de fevereiro de 1966, determinava-se eleições indiretas para governadores e prefeitos de municípios. O AI-4 serviu para legalizar por meio de uma Constituição outorgada, de 1967, as medidas autoritárias dos Atos Institucionais anteriores. O auge do autoritarismo se deu com a imposição do AI-5 em dezembro de 1968, em que os presidentes tinham poderes quase absolutos, pois podiam além de fechar o Congresso e derrubar políticos, poderiam também suspender habeas corpus, estabelecer a censura e qualquer pessoa punida pelo AI-5 não poderia ser julgada nos tribunais.

Enquanto o autoritarismo militar persistia no governo, a oposição intensificava as reivindicações e seu movimento de maior relevância foi a campanha das "Diretas-Já", visando introduzir uma emenda constitucional determinando que as próximas eleições presidenciais, em 1984, fossem realizadas através do voto popular direto. A campanha foi realizada por meio de comícios em todas as principais cidades brasileiras e sua maior representação foi em São Paulo reunindo mais de 1 milhão de pessoas.

A situação de repressão e inexistência da democracia teve seu fỉm, em 1985, quando Tancredo Neves vence a candidatura à presidência declarando o fim da Ditadura. No entanto, ele falecera antes de tomar posse e diante disso, entra seu vice José Sarney, um oligarca do nordeste brasileiro, estabelecendo uma transição para a democracia controlada por grupos oligárquicos.

O futuro do Brasil ainda era incerto, mas a volta da democracia e a promulgação de uma nova Constituição Federal traziam a esperança e a paz depois de 20 anos de ditadura. 


\subsection{Uma nova era}

A nova Constituição, promulgada em 1988, é considerada a mais democrática da História do Brasil. Nela encontramos itens que representam a democracia como por exemplo, o sufrágio universal para maiores de 16 anos e inclusive para analfabetos; o estabelecimento do pluripartidarismo; o fim da censura; o direito à greve; a autonomia sindical e muitas outras concessões que impulsionariam o Brasil para uma nova era política.

O preâmbulo constitucional salienta:

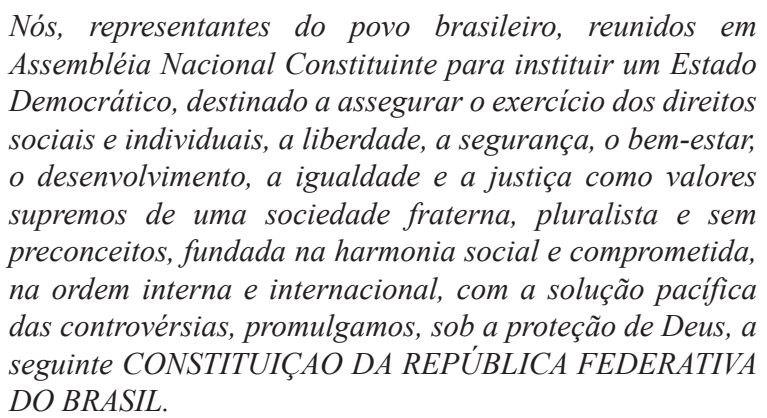

Sendo assim, a Constituição da República Federativa do Brasil tem em seu conteúdo medidas para trazer ideais como a igualdade, o bem-estar social para a realidade com o objetivo de unir toda a nação e diminuir as desigualdades sociais.

No entanto, hoje, parece que estamos vivendo uma crise de degenerescência da democracia representativa, pois toda a teoria idealizada na Lei Máxima parece não surtir efeito. Bastaria analisarmos o elemento fundamental de uma democracia representativa, os partidos políticos.

\section{Capítulo III}

\section{A análise da Democracia.}

Para o jurista Dalmo de Abreu Dallari, ${ }^{17}$ para se ter um Estado Democrático deverão ser atingidos determinados pressupostos:

A eliminação da rigidez formal. Não haveria um Estado Democrático com uma forma pré-estabelecida. Para que o Estado seja democrático, ele deve atender

\footnotetext{
17 DALLARI, Dalmo de Abreu. Elementos da teoria geral do Estado. 25. ed. São Paulo: Saraiva, 2005.
} 
a concepções de valores fundamentais de certos povos em determinada época, logo deve existir uma certa flexibilidade do Estado para se adaptar a cada exigência de cada circunstância. Sendo assim, não podemos fixar um modelo democrático válido para todas as épocas e todos os tempo.

A supremacia da vontade do povo. Deve-se prevalecer a vontade do povo sobre a de qualquer indivíduo ou grupo. A Democracia implicaria em autogoverno, exigiria que os próprios governados decidam sobre as diretrizes políticas fundamentais do Estado. E pelo fato de o povo ser uma unidade heterogênea, temos que ter a certeza que sua vontade fora livremente formada, e depois de formada essa vontade deve ser livremente externada, ou seja, livre de qualquer tipo de coação ou vício de qualquer espécie. E pelo fato de todo homem ser dotado de inteligência e ser, portanto, um animal racional, é inerente se pensar que a convivência humana traz muitas divergências entre os semelhantes, assim, deve-se ter o direito de divergir.

A preservação da liberdade. O homem sendo um ser social, ou melhor, zoopolítico, não consegue viver isolado, salvo certos casos como um acidente, que separara um homem da sociedade, a debilidade mental ou o ermitão que se encontra em um nível à parte da sociedade. Sendo assim, a liberdade humana é uma liberdade social que traz consigo os deveres e as responsabilidades.

E a preservação da igualdade. Seria a concepção de uma igualdade de possibilidades, pois ela admite relativas desigualdades, decorrentes de mérito individual, aferido-se este através da contribuição de cada um à sociedade.

Portanto, Dallari traça meios de se ter um Estado Democrático ideal e real.

No entanto, no conceito do professor Fabio Konder Comparato, essa ideologia é inexistente como podemos comprovar em seu livro Ética, ${ }^{18}$ quando afirma que a democracia moderna teria sido a invenção dos norte-americanos e posteriormente adotada pelos franceses. E o mecanismo da representação popular constituíra na realidade, em um claro impedimento à soberania do povo. Ele servira, portanto, para encobrir sob uma aparência democrática a consolidação do sistema oligárquico, isto é, o regime de soberania dos ricos. Para Comparato, a pior democracia ainda é melhor que a melhor das ditaduras, mas ele percebe que há falhas no sistema democrático que resulta na situação atual do Brasil. A democracia seria uma espécie de camuflagem de dominação das camadas elitistas.

${ }^{18}$ COMPARATO, Fabio Konder. Ética: direito, moral e religião no mundo moderno. São Paulo: Cia das Letras, 2006. 
Portanto, a democracia brasileira foi, desde o começo da colonização, um reduto de elites pensantes em detrimento das camadas excluídas da população. Mesmo após a Proclamação da República, a esperança de mudanças foi eliminada quando os velhos nomes do Império ainda permaneciam no poder. Era um continuísmo do Império com nome de democracia republicana.

As eleições eram a concretização da ilusão democrática representativa, pois mesmo com o voto, era uma pequena parcela da população que poderia ia às urnas. $\mathrm{O}$ próprio sistema de eleitoral era excludente e restrito aos grandes fazendeiros, oligarcas, "coronéis".

Temos na Era Vargas mudanças grandiosas na economia como a entrada do Brasil na participação no setor secundário, o investimento na indústria de base, trazendo crescimento até então estagnado pela predominância do modelo agrário-exportador. E ainda houve o fortalecendo das camadas médias e pobres pela criação de empregos e pela promulgação de leis, protegendo os trabalhadores urbanos. Embora parecesse-nos que a sociedade estava no caminho certo, tudo foi desmascarado com a implantação de uma ditadura em mãos de Vargas.

O "Plano Cohen" fora uma farsa para abalar a consciência nacional e estar mais receptível a uma repressão em favor de uma reconstrução democrática. Para Getúlio garantir o poder e a repressão, foram adotadas medidas paternalistas, a fim de camuflar suas atitudes autoritárias e receber aplausos do povo urbano enganado.

Sabe-se que Getúlio Vargas não era um civil qualquer; ele fazia parte de um rol de oligarquias dissidentes às oligarquias cafeeiras, logo sua natureza elitista. Portanto, suas atitudes benevolentes ao povo foram para camuflar a população e ganhar prestígio de uma camada que se fortalecia cada vez mais.

Nesse período, a democracia representativa, apesar de se ter modificado em determinados setores da sociedade, por exemplo, na concessão do voto às mulheres e analfabetos dando um baque no patriarcalismo, fora claramente derrubada por meios ilícitos, mas aprovado pelos iludidos da população.

Posteriormente, encontramos, na Segunda República, uma volta da democracia representada por partidos políticos heterogêneos, de ideologias diversas. Nesse período, as alianças partidárias elitistas dominaram o cenário político novamente elegendo seus representantes para a defesa de interesses pessoais.

Isso até a implantação da Ditadura Militar. O regime assassinou a democracia no País e eliminou qualquer vestígio de representação popular. A repressão e a implantação 
de um bipartidarismo transformaram as idéias democráticas em nada. Os rebeldes ao sistema foram perseguidos e repreendidos, quando não executados.

Passados 20 anos, o Brasil renascera com ideais e propostas vincadas nos Direitos Humanos, no Bem-Estar e a nova Constituição Federal, de 1988, implantara ideologias que seriam defendidas pela redemocratização baseada na representação política efetiva em que os partidos políticos brasileiros gozariam de liberdade e autonomia para defender os interesses da população. A nova Lei Máxima trouxera esperança para o povo brasileiro.

\section{Capítulo IV}

\section{Os Partidos Políticos.}

Hoje não é comum se encontrar alianças partidárias cujas siglas têm ideologias antagônicas. A pergunta é: será mesmo que os partidos políticos seguem realmente suas ideologias ou será que na política não podemos pensar em ética, a tal ponto dos políticos não precisarem seguir suas siglas? Sabemos que na Idade Média o exercício do poder político foi aos poucos se desvinculando dos velhos costumes éticos, e tendendo a ser visto como uma atividade livre de toda injunção moral ou obediência religiosa; isso cabe ainda ao mundo moderno?

\subsection{Partidos Políticos no Brasil estabelecidos Constituição Federal de 1988}

O professor Alexandre de Moraes salienta em seu livro ${ }^{19}$ que a Constituição Federal regulamentou os partidos políticos como instrumentos necessários e importantes para a preservação do Estado Democrático de Direito, afirmando a liberdade de criação, fusão, incorporação e extinção de partidos políticos, resguardados a soberania nacional, o regime democrático, o pluripartidarismo, os direitos fundamentais da pessoa humana e observados os preceitos de caráter nacional; proibição de recebimento de recursos financeiros de entidade ou governo estrangeiros ou de subordinados a estes; prestes de contas à Justiça Eleitoral e funcionamento parlamentar de acordo com a lei.

Além disso, a Constituição Federal assegura aos partidos políticos autonomia para definir sua estrutura interna, organização e funcionamento, devendo seus estatutos

\footnotetext{
${ }_{19}$ MORAES, Alexandre de. Direito constitucional. 19. ed. São Paulo: Atlas, 2006.
} 
estabelecer normas de fidelidade e disciplinas partidárias, sendo vedada a utilização pelos partidos políticos de organização paramilitar.

E os partidos políticos, após adquirirem personalidade jurídica, na forma da lei civil, registrarão seus estatutos no Tribunal Superior Eleitoral e terão direito a recursos do fundo partidário e acesso gratuito ao rádio e à televisão, na forma da lei.

E com o intuito do legislador constituinte diminuir o controle do Poder Público dos partidos políticos e aumentar a autonomia dos mesmos, Michel Temer citado por Alexandre de Moraes explica:

tentar criar (ou fortalecer) partidos políticos sólidos,
comprometidos com determinada ideologia político-
administrativa, uma vez que o partido há de ser o canal
condutor a ser percorrido por certa parcela da opinião
pública para chegar ao governo e aplicar seu programa.

O jurista lembra que apesar dos partidos políticos serem os principais operadores políticos em um regime democrático, os partidos não seriam os únicos, haveria ainda a possibilidade de tutela dos interesses setoriais como grupos ecológicos, feministas, pacifistas através de associações e grupos de pressão.

Inferimos que as pessoas, nessa última Constituição, estão livres para se associarem e formarem uma unidade partidária, a fim de defender interesses de uma coletividade. Os partidos políticos receberam certa autonomia para que pudessem agir e influenciar os indivíduos desde que não tivessem intenções paramilitares, e assim, constituir um Brasil democrático em que os cidadãos se identificariam com as diversas ideologias representadas por siglas. E estas, por sua vez, servirem como uma caixa de ressonância das vontades do povo.

\subsection{Um sinônimo de atraso}

O coronelismo, espécie de mandonismo local, comum na Primeira e Segunda República e ainda presente nos dias de hoje, é retratado em Raízes do Brasil ${ }^{20}$ como uma força a parte em que "a autoridade do proprietário de terras não sofria réplica. Tudo se fazia consoante sua vontade, muitas vezes caprichosa e despótica." Essa espécie de privilégio ainda persiste em existir porque o Governo, não-conseguindo suprir as necessidades de camadas pobres do interior, deixa com que os "coronéis" façam o papel de "pequeno estado" regulador. Assim, o Estado concede a ação dos grandes proprietários

\footnotetext{
${ }^{20}$ HOLANDA, Sérgio Buarque de. Raízes do Brasil. 26. ed. São Paulo: Cia das Letras, 1995.
} 
de terra e estes garantem o status quo da região e as eleições pela compra de votos por meio de currais eleitorais.

$\mathrm{Na}$ análise do regionalismo segundo Lília Mortis Schwanoma, ${ }^{21}$ este é concebido como mais um obstáculo à democracia do País. Os partidos brasileiros representariam meras somas de lideranças locais, uma vez que os cargos políticos permaneceriam concentrados nas mãos dos fazendeiros. Por sua vez, o Estado teria dificuldade de inserir-se nesse ciclo familiar, sendo em torno do privado que se construiria boa parte da organização política.

Desse modo, a existência de um mandonismo local remete ao Brasil a períodos da Idade Média em que os feudos eram o centro do território nacional. Os grandes senhores-de-engenho possuíam o poder político e dominavam a população pela força e dinheiro. Esse atraso político reflete a um País pouco forte, ou pouco preocupado para com seu povo.

Em Raízes do Brasil,22 Sérgio Buarque de Holanda descreve um período ainda comum na atualidade, justificando a necessidade de uma mudança efetiva quanto ao poder concentrado dos latifundiários que ainda agem como verdadeiros déspotas sem essa legitimidade.

O Governo, portanto, sabe que concede privilégios aos "coronéis" e estes sabem que o Governo necessita dos seus apoios. Por conseguinte, de nada adiantaria um partido ideológico que lutaria pelas causas de um povo, pois se o próprio Estado adere a um poder paralelo, logo a representação se torna inútil e ineficaz.

Sendo assim, é urgente a diminuição do poder concentrado dos oligarcas e o incentivo de formação partidária pela união de pessoas realmente dispostas a lutar por causas de uma coletividade. É imperativo a democracia representativa em todo o País.

\subsection{A falta de uma ideologia}

Sérgio Buarque de Holanda transcreve em seu livro ${ }^{23}$ a frase: "Nada há mais parecido com um saquarema do que um luzia no poder" dita por Holanda Cavalcante sobre os dois partidos dos tempos da monarquia. Realmente podemos transpor essa frase para a atualidade em que partidos políticos opostos se unem para obter concessões.

\footnotetext{
${ }^{21}$ SCHWARCZ, Lilia Mortiz. O Estado de S. Paulo. Caderno Especial. Domingo, 05 de novembro de 2006.

${ }^{22}$ Id. Ibid.

${ }^{23}$ HOLANDA, Sérgio Buarque de. op. cit.
} 
As últimas eleições, realizadas em 2006, refletiram na figura criada no romance de Mário de Andrade, Macunaíma em que o escritor conseguia personificar o Brasil na forma que o "vale-tudo" dominou a vida em nossas terras desde a chegada das caravelas portuguesas. Macunaíma, "o herói sem nenhum caráter", é exemplar do brasileiro que, jogado na selva que sempre foi a nossa sociedade, tem que dar um jeitinho para sobreviver, não questionando o sistema, aproveitando as oportunidades que aparecem e procurando melhorar a vida passando ao largo de considerações sobre ética, legalidade, coerência pessoal ou preocupação de mudar o mundo. Os partidos políticos utilizaram a miséria e a carência que afligem a população brasileira como uma forma de dominação e compra de votos. Houve gastos exorbitantes em campanhas que chegam a ser grande parte da receita de países pobres africanos. Houve aliança entre partidos que antes digladiavam em horários políticos e depois se uniam para ganhar votos. Tudo converge para a busca do poder. A ideologia de cada partido é resumida em simples siglas sem conteúdo.

As disputas atuais não têm um caráter ideológico e a sociedade contemporânea não vai em busca de ideais e, sim, de interesses corporativistas. $\mathrm{O}$ embate ideológico cede lugar para o corporativismo societariado, a sociedade atual não tem mais o viés ideológico como ocorria no passado, por exemplo, na Guerra Fria, ou no Fascismo italiano, o Salazarismo em Portugal. Este corporativismo societal agrega interesses particulares e não são regulados pelo Estado, são regulados muitas vezes por interesses não-econômicos e sim por interesses próprios, interesses pelo poder.

Segundo Sérgio Buarque de Holanda, ${ }^{24}$ "Toda hierarquia fundase necessariamente em privilégios" e assim, quem está no poder não quer ceder seus privilégios e quem está fora do poder almeja alcançá-lo. Parece-nos que a frase supracitada tem grande relevância no momento das grandes decisões políticas. Talvez seja por essa razão que muitos partidos políticos se unam quando estão enfraquecendo, afinal, perder o poder, é perder privilégios.

É um dever, em meio a esta situação caótica, da população exigir, cobrar e reclamar contra essa incoerência partidária, pois quem detém o poder real em uma democracia representativa não é o partido, não é o governante, é o povo. Temos todos opiniões diferentes, pois somos indivíduos heterogêneos, formados por culturas diversas e os partidos políticos seriam o ideal para se representar a vontade geral, a vontade de uma maioria. Não há a completa representação, mas há a satisfação de uma maioria, portanto,

${ }^{24}$ HOLANDA, Sérgio Buarque de. Raízes do Brasil. 26. ed. São Paulo: Cia das Letras, 1995. 
para nos apegarmos em uma ideologia e acreditarmos em um futuro, ela deve ser seguida, devemos ter certeza de representação.

Sendo assim, o partido político não pode ser incoerente quanto aos seus ideais, se for, não é partido, é uma gangue de vendedores de ilusão, logo sua eliminação do sistema político é obrigatória e seus componentes devem ser devidamente punidos por enganar a toda uma coletividade.

\subsection{A questão do voto nulo}

O voto nulo pode significar a declaração da inexistência de uma ideologia a se seguir, ou também pode ser uma forma de manifestação contra a incoerência entre a sigla partidária e sua ideologia.

Cabe lembrar que, em época da ditadura, o voto secreto e democrático era proibido e os Atos Institucionais determinaram eleições indiretas para presidente, governador e prefeito. Apesar dessa experiência traumática, nas últimas eleições, de 2006, a população praticamente jogou votos ao lixo quando os defendeu conforme explica Ferreira Gullar $^{25}$ ao informar que os votos nulos chegaram a 20\% do eleitorado.

Isso foi conseqüência de uma sucessão de escândalos, envolvendo altos escalões do Governo e de partidos políticos concorrentes ao Poder Executivo. A acusação de que a atividade política é essencialmente corrupta induz muitos eleitores a uma decisão radical: anular o voto ou votar em branco. Essa é uma forma de manifestar, no mínimo, a revolta e o protesto perante as instituições da República.

Gullar afirma que, durante a ditadura, a oposição ao regime dividiu-se entre aqueles que acreditavam que era possível derrotá-lo pacificamente, exigindo a restauração das liberdades democráticas, e os que optaram pela luta armada e pregavam o voto nulo ou em branco. A conseqüência de tal atitude fora que embora a ditadura tivesse menos votos que a oposição, ganhava as eleições, uma vez que os votos oposicionados, somados aos nulos e em branco, superavam em muito os de apoio ao Governo. E, com isso, ao contrário do que afirmavam os adeptos da luta armada, legitimavam o regime.

André Franco Montoro Filho ${ }^{26}$ pensa que o voto nulo seria uma proposta sem propósito, portanto a população deveria focar em outros pontos como, em primeiro lugar, convencer a todos que as eleições para o Legislativo são tão importantes quanto as

\footnotetext{
${ }^{25}$ GULLAR, Ferreira. Voto nulo. Folha de S.Paulo. Ilustrada. página E12. Domingo, 3 de setembro de 2006.

${ }^{26}$ MONTORO FILHO, André Franco.Uma proposta sem propósito. Folha de S.Paulo. Tendências e Debates. página A3. Sábado, 9 de setembro de 2006.
} 
para presidente ou para governador, pois um Congresso bem estruturado e composto com deputados e senadores comprometidos com o povo é tão importante quanto o presidente preocupado com a nação ou o governador preocupado com o seu Estado. Em segundo lugar, o economista afirma que seria necessário insistir no exame das qualidades morais e no caráter dos candidatos. E depois seria preciso exigir individualmente ou coletivamente dos candidatos o compromisso com uma reforma eleitoral; e, por último, seria obrigatório cobrar dos eleitos o compromisso assumido.

Sendo assim, votar é uma obrigação do cidadão e também é um direito que ele conquistou no regime democrático e que lhe permite influir no destino da sociedade, elegendo seus governantes. Por isso, a atitude correta quando se criam as situações atuais é empenhar-se na seleção mais rigorosa possível na escolha dos candidatos, pois anular o voto, é anular todo o processo de busca de uma democracia representativa.

Conclusão

Não sabemos ao certo se o Brasil, sendo colonizado por portugueses, foi a causa dos problemas vividos. Em Raízes do Brasil, ${ }^{27}$ há um embate da questão da colonização protestante em diversos países da América em contrapartida da colonização ibérica. Enquanto o primeiro tipo de colonização visava o trabalho, a criação, o segundo buscava o ócio, a "boa vida", o jeito "Macunaíma-de-ser".

Sérgio Buarque de Holanda afirmava que "a democracia no Brasil sempre foi um lamentável mal-entendido". Para ele, o modelo protestante seria o mais adequado em nosso País. A "ética protestante" nos traria bons frutos e não a degradação que encontramos em muitas partes brasileiras.

Outros pensadores como Caio Prado Junior, citado pela antropóloga Lilia Schwarcz, ${ }^{28}$ tinha a certeza de que as mazelas da colonização explicariam os nossos principais obstáculos, dados pela monocultura, pelo latifúndio, pelo trabalho compulsório e por uma economia exportadora. Neste ponto, Sérgio Buarque de Holanda, em contraposição à colonização portuguesa, também concorda e acrescenta em sua teoria que o brasileiro teria a repulsa do trabalho regular, hábito que explicaria " $a$ vontade de mandar e a pequena disposição de cumprir". A tradição rural e as marcas da escravidão seriam os entraves do passado que refletiriam no futuro.

\footnotetext{
${ }^{27}$ HOLANDA, Sérgio Buarque de. Raizes do Brasil. 26. ed. São Paulo: Cia das Letras, 1995.

${ }^{28}$ SCHWARCZ, Lilia Mortiz. O Estado de S. Paulo. Caderno Especial. Domingo, 05 de novembro de 2006.
} 
Os mais variados estudos indicam que muitas feridas abertas no passado ainda permanecem abertas no presente. Por exemplo, a tradição rural, muito marcante desde o inicio da exploração do Brasil-colônia até os dias de hoje, detém muita força política em um Brasil agroexportador. O regionalismo, dominado pelos grandes senhoresde-terra, impede a penetração da democracia para uma camada interiorana que se encontra debilitada e aprisionada perante o sistema político local.

Nesse caso, percebemos além da repressão local, uma ausência do Estado de zelar pelos Direitos Fundamentais dos cidadãos brasileiros, pois ao deixar o mandonismo local se sobrepor à Constituição Federal, declara-se fraco e pouco preocupado com a democracia brasileira, com o povo brasileiro.

Sendo assim, não podemos ser indiferentes perante um problema desses. Quando se percebe uma democracia fraca, o detentor do poder, conforme explicita a Constituição Federal, de 1988: “Artigo $1^{\circ}$ Parágrafo único. Todo poder emana do povo, que o exerce por meio de representantes eleitos ou diretamente, nos termos desta Constituição", deve agir. A melhor ação é ir às urnas eleitorais, é escolher o representante do povo.

Entretanto ao anular o voto, jogamo-no ao lixo e privamo-nos de um poder transformador. Cabe lembrar que a Ditadura fora repudiada por pelo menos um milhão de pessoas nas ruas na campanha das "Diretas-Já", visando o voto popular e seu fim foi comemorado pela volta da democracia representativa.

Devemos, pois, usar a melhor arma contra a corrupção, contra a infidelidade partidária, contra a fraca atuação estatal, o voto. Não podemos simplesmente votar, temos de acompanhar a trajetória de nosso representante escolhido para conferir se sua atuação realmente condiz com o esperado; caso contrário, devemos requerer a cassação de seu mandato pelo não-cumprimento do contrato.

Além disso, a fidelidade partidária e a concordância das siglas partidárias com a ideologia proposta devem ser obrigatórias, pois não podemos nos identificar com uma idéia defendida por um partido político sendo que este não a segue. É comum, atualmente, os partidos políticos buscarem interesses próprios e não interesses da vontade geral. Isso gera o colapso da democracia. Portanto, a melhor saída está nas mãos do povo e seria a boa escolha, o voto consciente e a exigência do cumprimento das promessas oferecidas ao eleitor.

Talvez assim possamos ter uma democracia calcada nos interesses do coletivo e não nas vontades de uma minoria. 


\section{Referências}

COMPARATO, Fabio Konder. Ética: direito, moral e religião no mundo moderno. São Paulo: Cia das Letras, 2006.

COSTA, Luis Cesar Amad; MELLO, Leonel Itaussu A. História do Brasil. 11. ed. São Paulo: Ed. Scipione, 2002.

DALLARI, Dalmo de Abreu. Elementos de teoria geral do Estado. 25. ed. São Paulo: Saraiva, 2005.

FERREIRA, Olavo Leonel. História do Brasil. 8. ed. São Paulo: Ed. Ática, 2005.

GRANDE Enciclopédia Larousse Cultural, Ed. Nova Cultural.

GULLAR, Ferreira. Voto nulo. Folha de S. Paulo. Ilustrada. página E12. Domingo, 3 de setembro de 2006.

HOLANDA, Sérgio Buarque de. Raízes do Brasil. 26. ed. São Paulo: Cia das Letras, 1995.

MONTORO FILHO, André Franco. Uma proposta sem propósito. Folha de S. Paulo. Tendências e Debates. página A3. Sábado, 9 de setembro de 2006

MORAES, Alexandre de. Direito constitucional. 19. ed. São Paulo: Atlas, 2006.

NADAI, Elza; NEVES, Joana. História do Brasil. 20. ed. São Paulo: Ed. Saraiva, 1997.

SCHWARCZ, Lilia Mortiz. O Estado de S. Paulo. Caderno Especial. Domingo, 05 de novembro de 2006.

VICENTINO, Claudio; DORIGO, Gianpaolo. História do Brasil. 1. ed. São Paulo: Ed. Scipione. 1999.

WEBER, Max. Ensaio de Sociologia. Rio de Janeiro: Zahar Editores, 2000.

WEFFORT, Francisco C. A formação do pensamento político brasileiro. 1. ed. São Paulo: Ed. Ática, 2006.

. Os clássicos da política. 13. ed. São Paulo: Ed. Ática, 2005 . v. 1. 